\title{
Sediment deformation and basal dynamics beneath a glacier surge front: Bakaninbreen, Svalbard
}

\author{
Philip R. Porter, ${ }^{1 *}$ Tavi Murray, ${ }^{1}$ Julian A. Dowdeswell ${ }^{2}$ \\ ${ }^{1}$ School of Geography, University of Leeds, Leeds LS2 97T, England \\ ${ }^{2}$ Centre for Glaciology, Institute of Earth Studies, University of Wales, Aberystwyth Sr23 3DB, Wales
}

\begin{abstract}
Bakaninbreen is a $17 \mathrm{~km}$ long surge-type glacier in southern Spitsbergen, Svalbard, which began surging between the springs of 1985 and 1986, forming a surge front where fast-moving surge ice meets non-surging ice. This surge front has propagated $6 \mathrm{~km}$ down-glacier over the period to 1995. Instruments known as "ploughmeters" were installed into the deformable sedimentary bed close to the surge front to assess mechanical conditions year-round. Forces experienced by ploughmeters located down-glacier of the surge front are generally lower than those recorded by a ploughmeter up-glacier of the surge front. Ploughmeters installed at the bed down-glacier of the surge front show initially low applied forces, followed by increasing applied forces. We interpret this increase in applied forcing as a late-active-phase motion event. Analysis of ploughmeter data allows calculation of the yield strength of basal sediments. Yield-strength estimates at Bakaninbreen are in the range $16.6-87.5 \mathrm{kPa}$. Comparison with estimates of basal shear stress suggests that sediments up-glacier of the surge front will be actively deforming, whereas there will be only limited deformation down-glacier of the surge front. Immediately downglacier of the surge front, calculations indicate negligible basal shear stresses. Together with the deformation of sediment from up-glacier, this implies a build-up of sediment at the surge front, offering a potential explanation for the sediment-filled thrust faults outcropping on the surge front.
\end{abstract}

\section{INTRODUCTION}

Glacier basal motion may occur by several processes: where ice rests on a rigid substrate, basal motion is thought to result mainly from sliding at the ice/bed interface; where ice rests on unconsolidated sediments basal motion can additionally be caused by deformation of these sediments. In situ observations by Boulton and Jones (1979) at the margin of Breidamerkurjökull, Iceland, show that up to $88 \%$ of the glacier's surface velocity may be accounted for by deformation of water-saturated basal sediments. Work conducted on Ice Stream B, West Antarctica, has shown that basal sediment deformation may explain how fast-flow velocities can be maintained in the absence of large driving stresses, basal shear stress only reaching $20 \mathrm{kPa}$ in this case (Blankenship and others, 1986). In situ studies at the bed of Trapridge Glacier, Yukon Territory, Canada, show that basal sediment deformation accounts for approximately $10-50 \%$ of surface velocity, and suggest that it is an important factor in initiating and maintaining surging (Clarke and others, 1984; Blake and others, 1994).

In order to fully understand the details of glacier motion on a deformable substrate, an adequate rheological description of basal sediments is required. The only complete rheology has been derived for basal sediments at Breiðamerkurjökull; however, this was based on a relatively small data

* Present address: Department of Geography, University of Manchester, Manchester M13 9PL, England. set of seven points, gained from measurements made beneath thin, marginal ice where basal conditions may not be representative of those beneath the remainder of the ice mass (Paterson, 1981; Boulton and Hindmarsh, 1987). Assessments of the rheologic properties of basal sediments have been made by several workers; however, the only in situ assessments of basal-sediment rheologic properties have come from Breiðamerkurjökull (e.g. Boulton and Jones, 1979), Columbia Glacier, Alaska (Humphrey and others, 1993), Trapridge Glacier (e.g. Fischer and Clarke, 1994) and Storglaciären, Sweden (Iverson and others, 1994), no such measurements having been undertaken in the high Arctic. In situ monitoring of basal sediment properties beneath high-Arctic glaciers is especially important, given the large numbers of surge-type glaciers concentrated in Svalbard, and the potential role of basal sediment deformation in the surge process.

\section{FIELD SITE}

During 1994 and 1995 we instrumented the bed of Bakaninbreen, a surge-type valley glacier in southern Spitsbergen, Svalbard, with in situ mechanical sensors. Bakaninbreen began surging in 1985-86, and a large "bulge" or surge front has developed where fast-moving surge ice meets non-surging ice. This surge front has propagated down-glacier (Dowdeswell and others, 1991; Hambrey and others, 1996), in the form of a "compressive wave", associated with the development of thrusts and shear zones (Hambrey and others, 1996). At the height of the surge, max- 
imum flow velocities of $4.7 \mathrm{~m} \mathrm{~d}^{-1}$ were recorded, and the surge front evolved into a steep wall of ice (Dowdeswell and others, 1991). Surge-front propagation has slowed since 1989, and the surge front has ablated to a gentle ramp, some $50-60 \mathrm{~m}$ in elevation with a maximum slope of $20^{\circ}$ (Hambrey and others, 1996). As part of an ongoing research programme investigating surge dynamics at Bakaninbreen (Murray and Porter, 1994; Porter and Murray, 1995; Hambrey and others, 1996), an extensive hot-water drilling campaign was undertaken during 1994 and 1995 both up-glacier and down-glacier of the surge front. Drilling has allowed samples of basal sediment to be extracted, and has demonstrated that Bakaninbreen overrides a layer of soft sediments, at least $1 \mathrm{~m}$ thick (Murray and Porter, 1994). The basal sediments comprise a mixture of marine muds and glacial till (Hambrey and others, 1996).

\section{METHODS}

Devices known as "ploughmeters" were installed at the bed of Bakaninbreen, both up-glacier and down-glacier of the surge front (Fig. 1). Ploughmeters enable us to assess rheologic properties of basal sediments such as yield strength, and may also be used to infer sediment texture and assess glacier sliding rates (Fischer and Clarke, 1994; personal communication from U.H. Fischer, 1996). The instrument consists of a $2 \mathrm{~m}$ long steel rod machined to a point at one end. The rod is hammered into basal sediments such that the upper part becomes trapped within glacier ice. As the glacier moves over its bed, the rod is dragged through the sediments (Fig. 2). Two pairs of strain gauges situated perpendicular to one another are bonded to the pointed, immersed section of the rod. The gauges are wired as two separate full bridges, with bridge completion resistors situated as close to the strain gauges as possible. These gauges respond to elastic bending of the rod as the device ploughs through basal sediments.

The ploughmeter is calibrated in the manner described by Fischer and Clarke (1994). The device is clamped to a flat bench, with the strain gauges overhanging the bench edge. The tip of the ploughmeter is then incrementally loaded with weights. The ploughmeter is rotated through $360^{\circ}$ in $15^{\circ}$ steps and reloaded. This loading process alters the resistance of the strain gauges and unbalances the bridges. A

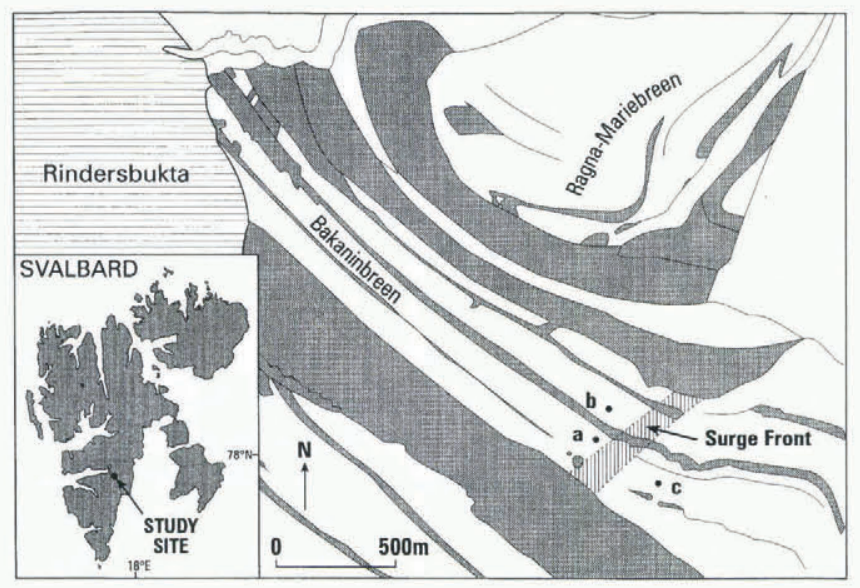

Fig. 1. Map of Bakaninbreen, Svalbard, showing location of surge front in 1995 (cross-hatched) and position of ploughmeter placements: (a) PL-2, (b) PL-3, and (c) PL-5.

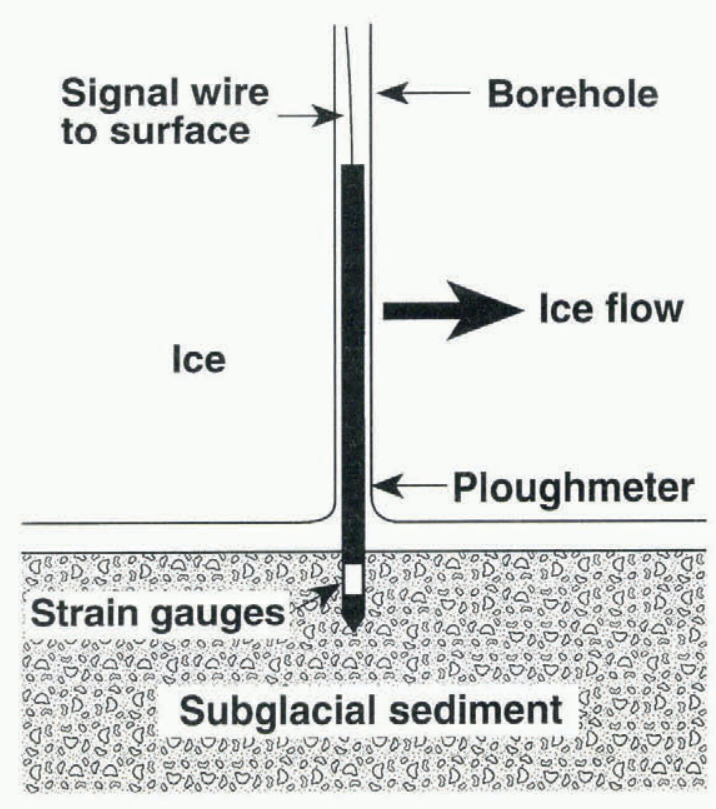

\section{Fig. 2. Schematic diagram showing a ploughmeter installed at the glacier bed. The ploughmeter is hammered into basal sedi- ments such that the upper part becomes trapped within glacier ice. Strain gauges bonded to the immersed section respond to elastic bending of the ploughmeter as the device is dragged through basal sediments by the motion of the glacier.}

Campbell CR10 data logger is used to apply an excitation voltage to the bridges; if the bridges are unbalanced, a differential voltage signal is generated. This voltage output is proportional to the magnitude and direction of force experienced by the ploughmeter. At Bakaninbreen, ploughmeters were wired to Campbell CR10 data loggers using multiplexer boards. During summer, measurements were taken at $2 \mathrm{~min}$ intervals; in winter and spring this sampling rate was reduced to 40 and $20 \mathrm{~min}$, respectively.

Once the ploughmeter is installed at the bed, its orientation in the borehole is unknown. The calculated values of force and direction are relative only to the internal coordinate system of the ploughmeter. However, if we assume that the principal direction of applied force is down-glacier, and orientate the average azimuth in this direction, then it is possible to decompose the force record into cross-glacier and down-glacier components (Fischer and Clarke, 1994).

\section{RESULTS}

Figure 3 shows long-term (14 months) force magnitude and direction (azimuth) records for ploughmeters installed at the bed of Bakaninbreen during 1994. Ploughmeters PL-2 and PL-3 were installed down-glacier of the surge front. These ploughmeters show initially low applied forces, followed by a period of steadily increasing applied forcing. This increase in applied force begins in October 1994 for ploughmeter PL-2, and in May 1995 for ploughmeter PL-3. Ploughmeters PL-2 and PL-3 experience mean applied forces of 792 and $508 \mathrm{~N}$, respectively, with maximum recorded applied forces of $1697 \mathrm{~N}$ on 15 June 1995 for PL-2, and 615 N on 4 July 1995 for PL-3. Ploughmeter PL-5, situated up-glacier of the surge front, shows forces an order of magnitude higher than ploughmeters installed at the bed down-glacier of the surge front, experi- 

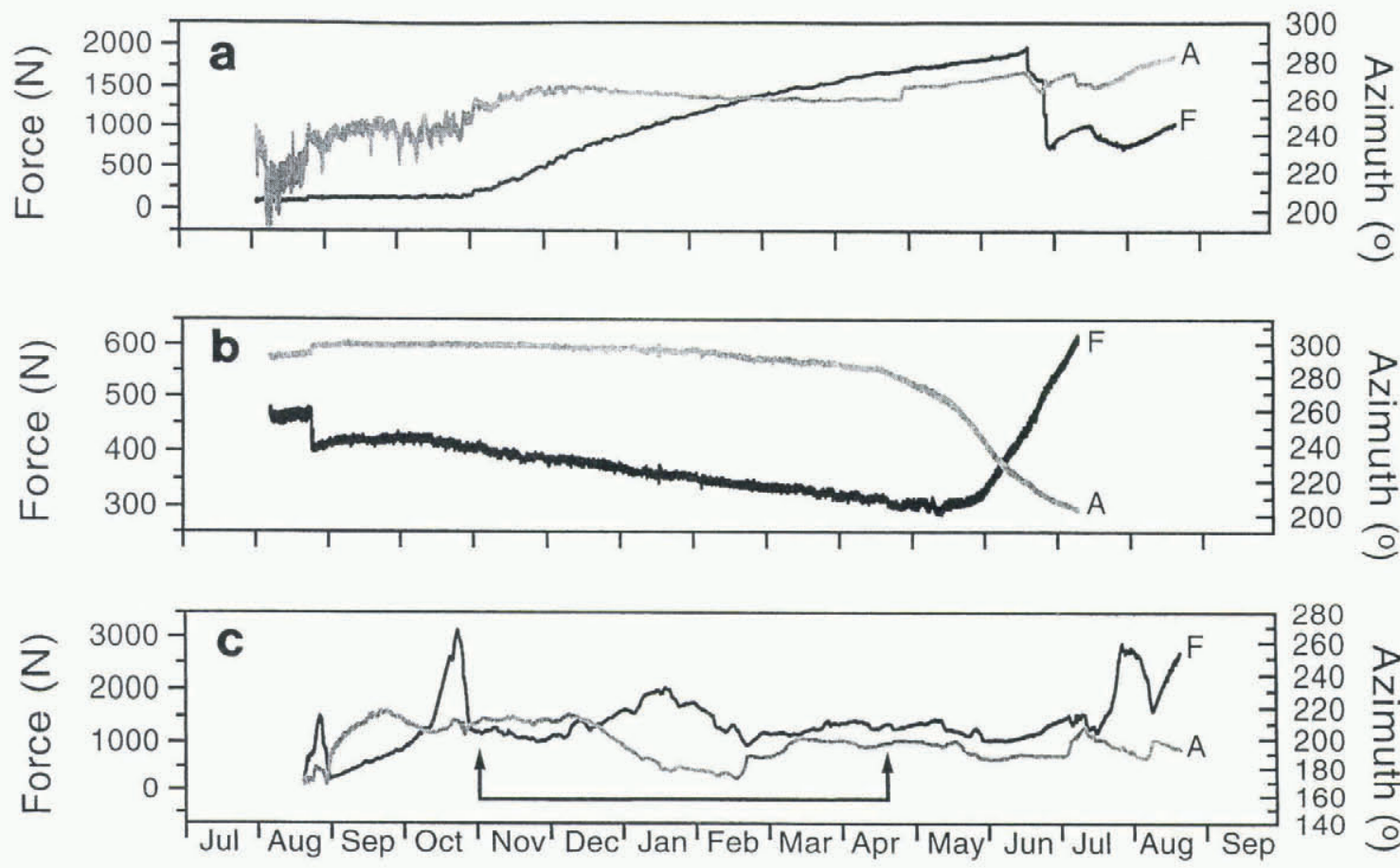

1994

1995

Fig. 3. Long-term force and azimuth records from ploughmeters: (a) PL-2, (b) PL-3 situated down-glacier of the surge front, and (c) PL-5 situated up-glacier of the surge front. Force and azimuth are labelled F and A, respectively. Note the steadily increasing force trace after October 1994 (PL-2) and May 1995 (PL-3). Ploughmeter PL-5 showes a more jagged force trace, consistent with ploughmeter motion through an area of coarse-grained bed. Arrows on (c) PL-5 indicate period over which yield-strength calculations have been made.

encing a mean applied force of $1330 \mathrm{~N}$ with a maximum of $3413 \mathrm{~N}$ on 21 October 1994.

\section{PROPERTIES OF BASAL SEDIMENT}

To determine the rheometric properties of basal sediments, an appropriate rheometric model is required. If it is assumed that basal sediment behaves as an ideal plastic solid, and that the ploughmeter approximates a flat, rigid indenter, then the yield strength, $k$, of the material may be calculated from

$$
k=\frac{L}{4 a c(2+\pi)},
$$

where $a$ is the radius of the ploughmeter, $c$ is the length of the immersed section of the ploughmeter, and $L$ is the applied force on the ploughmeter (Fischer and Clarke, 1994). Using this method, the yield strength of the till at Bakaninbreen is $16.6-87.5 \mathrm{kPa}$, with a mean value of $29.9 \mathrm{kPa}$. These values are comparable with values gained from other glaciers. Using ploughmeters installed at the bed of Trapridge Glacier, Fischer and Clarke (1994) obtained yieldstrength estimates in the range $48-57 \mathrm{kPa}$. Using an alternative in situ subglacial sensor called a "dragometer", Iverson and others (1994) obtained a mean yield strength estimate of $55 \mathrm{kPa}$ for sediment beneath Storglaciären.

\section{DISCUSSION}

Provided the upper section of the ploughmeter is fixed firmly in glacier ice, and that basal sediments exhibit viscous behaviour after yield, then variations in the magnitude of applied forcing can result from three potential causes, namely: (1) variations in glacier sliding velocity, (2) spatial variations in sediment granulometry, and (3) variations in basal sediment viscosity. Viscosity variations are in turn influenced by changes in effective pressure, deformation history, porosity, and rate of shearing. If the ploughmeter is not firmly held in glacier ice, then variations in applied force may additionally result from movement of the ploughmeter away from the vertical. This effect is unlikely to represent a large source of error, as the borehole diameter relative to ploughmeter length is such that vertical rotation would be restricted. Equally, it is possible that small variations in vertical orientation of the ploughmeter within the borehole may result from pressure melting and refreezing (regelation). In common with Fischer and Clarke (1994), we believe that this effect will be negligible due to the insulating properties of the resin and plastic sheath surrounding the instrument. However, if this process does occur, then it will tend to reduce the applied force experienced by the instrument.

The relatively high and variable applied forces experienced by ploughmeter PL-5 situated up-glacier of the surge front could result from a combination of any of the factors outlined above. However, we believe these higher applied forces are primarily caused by enhanced sliding based on the following evidence. First, observed sliding rates are higher up-glacier of the surge-front. A "drag-spool" (Blake and others, 1994; Porter and Murray, 1995) installed at the bed shows an average sliding rate of $0.002 \mathrm{~m} \mathrm{~d}^{-1}$, whereas drag-spools installed down-glacier of the surge front show negligible sliding rates. Secondly, the "jagged" nature of the force trace is hard to explain using small-scale spatial changes in sediment viscosity, but is consistent with move- 
ment through an area of coarse-grained bed material (Fischer and Clarke, 1994). Finally, changes in effective pressure appear not to be driving-force variations in this instance. Although no independent measure of pore-water pressure is available, borehole pressure transducers have frequently been used to provide a surrogate measure (Murray, 1994). Pressure transducers located in the study area show no relationship with applied force experienced by ploughmeters.

We interpret the steady increase in applied force experienced by ploughmeters PL-2 and PL-3, as an increase in glacier sliding rate down-glacier of the surge front caused by a late-active-phase movement of the surge front. This movement of the surge front has essentially "activated" ploughmeters PL-2 and PL-3 located close to the base of the surge front, resulting in an increase in applied forcing. We base this interpretation on the following evidence. First, the smooth nature of the increasing force trace is indicative of a gradual, steady increase in applied force, consistent with a steady increase in sliding velocity, movement through a region of bed with viscosity that increases systematically down-glacier, or a steady decrease in pore-water pressure. We believe that the magnitude of this steady applied force increase is unlikely to result from spatial viscosity changes alone. Effective pressure variations might offer an explanation for the observed force increase. However, as we have previously indicated, borehole water-pressure measurements show no correlation with the observed force variations. Secondly, thrust faulting has been identified as a mechanism allowing down-glacier propagation of the surge front at Bakaninbreen (Hambrey and others, 1996). Fresh thrust faulting formed on the surge front between our 1994 and 1995 field seasons, suggesting some activity of the surge front during this period. Finally, down-glacier displacement of survey tripods located on the surge front was observed in 1995 (personal communication from D. Orton, 1995). These tripods were installed in centre-line positions during 1994, and their displacement during 1994-95 indicates a movement event in the intervening winter period.

\section{CALGULATION OF BASAL SHEAR STRESS}

Basal shear stresses were calculated for centre-line survey points on Bakaninbreen using the method proposed by Kamb and Echelmeyer (1986). This method takes into account the effects of longitudinal stress gradients, using the equation

$$
\tau_{\mathrm{b}}(x)=\frac{1}{2 \ell h^{\frac{1}{n}}} \int_{-\infty}^{+\infty} \tau_{\mathrm{L}}\left(x^{\prime}\right) h^{\frac{1}{n}}\left(x^{\prime}\right) \exp -\left|x^{\prime}-x\right| / \ell \mathrm{d} x^{\prime},
$$

where $\tau_{\mathrm{b}}$ is basal shear stress, $\tau_{\mathrm{L}}$ is local slope stress, $n$ is the exponent in Glen's flow law, here taken to be $3, x$ represents surface coordinates on the glacier centre line, $\ell$ is the longitudinal coupling length (i.e. the length scale over which the effects of changes in ice thickness and surface slope are averaged), and $h$ is ice thickness. Kamb and Echelmeyer found that for valley glaciers the ratio of $\ell / h$ tends to fall into the range 1.5-2.5. Therefore, following the analysis of Hamilton (1992), longitudinal coupling length was set at twice the ice thickness for every surface coordinate at which shear stress was calculated. Ice thickness values are taken from drilling records. Maximum calculated shear stress using this technique is $98 \mathrm{kPa}$, with a mean of $26 \mathrm{kPa}$.

\section{BASAL SEDIMENT DYNAMICS}

By comparing the yield strength and shear stress calculations, it is possible to identify areas of potential sediment deformation (Fig. 4). Down-glacier of the surge front, shear stress rarely exceeds the minimum calculated yield strength, implying that shearing of sediment is limited in this region. Conversely, up-glacier of the surge front, shear stress consistently exceeds the mean calculated yield strength, and in the region of the surge front exceeds maximum calculated yield strength. This implies that deformation of sediment is likely to be occurring in these regions. However, the possibility that certain areas of the bed may be supporting higher than average levels of shear stress, thereby reducing shear stress to below the sediment yield
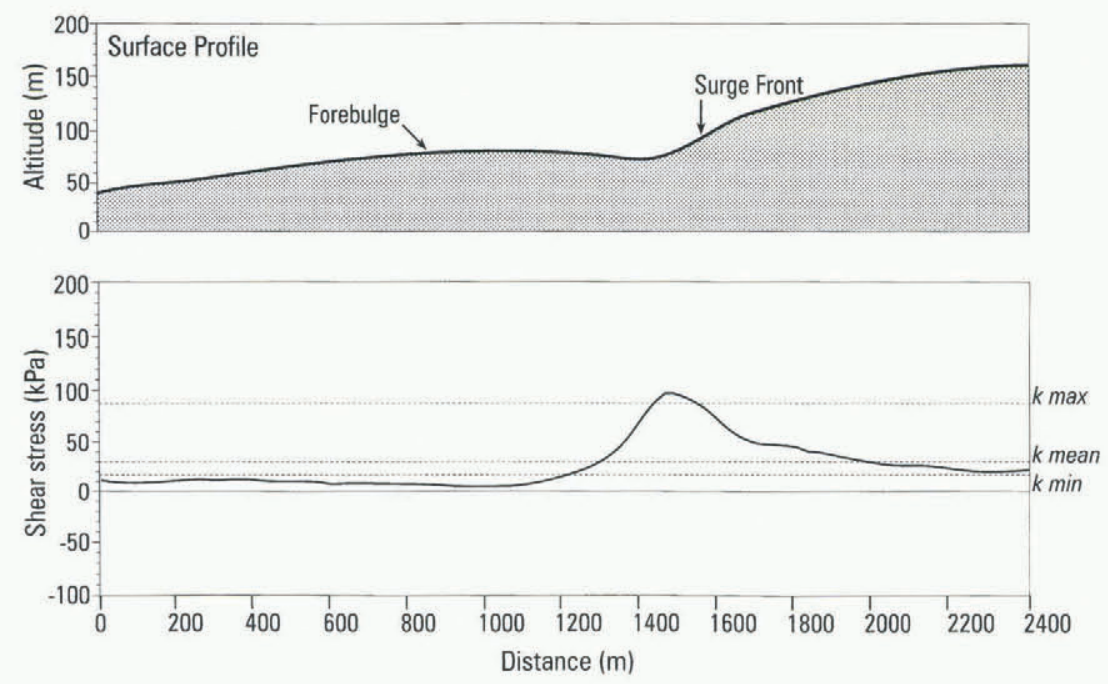

Fig. 4. 1995 surface profile of Bakaninbreen, showing basal shear stress calculated from Equation (2). Maximum, minimum and mean basal sediment yield strengths calculated from Equation (1) are shown as horizontal dashed lines. Minimum basal sediment yield strength is consistently exceeded up-glacier of the surge front. Basal sediments in this region are therefore likely to be deforming. 


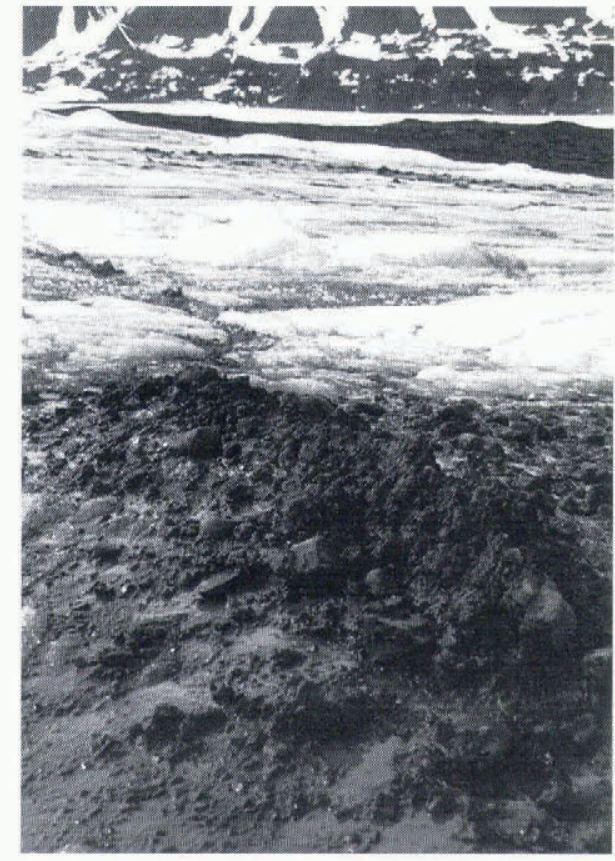

Fig. 5. Thrust fault on the surge front at Bakaninbreen. Basally derived debris emerges from the fault, forming an apron of debris on the glacier surface.

strength across large areas of the bed, cannot be discounted. These so-called "sticky spots" may occur in areas where basal sediment is absent (Iverson and others, 1995). Any bedrock protuberance of significant size may then be able to support larger than average shear stresses (Alley, 1989). Evidence from drilling and sediment sampling suggests that in the observation area, Bakaninbreen is underlain by a spatially extensive sediment layer at least $1 \mathrm{~m}$ thick (Murray and Porter, 1994). Furthermore, surface features such as localised crevassing, which may indicate the presence of such a protuberance, are absent.

Immediately down-glacier of the surge front, longitudinal compression caused by the propagation of the surge front has resulted in uplift of the glacier surface, forming a compressive tectonic structure that we term a "forebulge" (Fig. 4). The resultant reverse surface slope immediately down-glacier of the surge front results in decreasing shear stress in the region of the forebulge (Fig. 4), which is likely to hinder the transport of sediment down-glacier. Together with the deformation of sediments from up-glacier, this stress gradient implies a potential build-up of sediment in this area.

Thrusting is an important process on surge-type glaciers, providing a mechanism whereby down-glacier propagation of a surge front is possible, and allowing transport of large volumes of basal debris to englacial and supraglacial positions (Clarke and Blake, 1991; Hambrey and others, 1996). Structural investigations conducted on Bakaninbreen have shown that high-angle thrust faults are partially responsible for the propagation of the surge front, and that some of these faults incorporate basal debris from the bed, lifting it to the surface to form linear ridges up to $1 \mathrm{~m}$ high (Fig. 5; Hambrey and others, 1996). Subsequent radar surveys (Murray and others, 1997) have confirmed that some of these features are englacially extensive, while many sediment-filled blind thrusts are also present. Given the apparent accumulation of basal sediment in the region of the surge front, it seems likely that incorporation into thrust faults, combined with resultant transport towards the surface, is a method of purging the glacier bed of excess sediment.

\section{CONCLUSIONS}

Data from ploughmeters installed at the bed of Bakaninbreen indicate a late-active-phase motion event. Even though the surge began in 1985, some down-glacier motion of the surge front is still occurring. Such indistinct surge termination and lengthy active phase are characteristics that have been observed on other Svalbard surge-type glaciers (Dowdeswell and others, 1991). By comparing the yield strength of basal sediments to the basal shear stress, we are able to determine regions of potential sediment deformation. Down-glacier of the surge front, sediment deformation appears to be limited; up-glacier of the surge front, it seems likely to be more widespread, which may result in the accumulation of sediment in the region of the surge front. Thrust faults bearing basally derived debris offer a potential mechanism for the removal of basal sediments in this region, to englacial and supraglacial positions.

\section{ACKNOWLEDGEMENTS}

This research was funded by grants from the U.K. Natural Environment Research Council (GT3/9031) and EU (EN5V-CT93-0299). Personal support to P.R.P. is provided by a University of Leeds School of Geography studentship. The School of Geography provided funding for our hotwater ice drilling system. We are grateful to S. Onarheim and F. Olsen (Norsk Polarinstitutt, Oslo) for enabling field logistics, and to R. Odegård and J. -O. Hagen for their invaluable help with pre-field-season preparations. Thanks are also due to A. Fox, D. Garbett, D. Gooch, M. Hambrey, A. Hiatt, A. -M. Nuttall, D. Orton and M. Purrett for valuable assistance in the field. Reviews by Dr N. R. Iverson and Prof. G. S. Boulton significantly improved this paper.

\section{REFERENGES}

Alley, R. B. 1989. Water-pressure coupling of sliding and bed deformation: II. Velocity-depth profiles. F. Glaciol., 35 (119), 119-129.

Blake, E.W., U. H. Fischer and G. K. C. Clarke. 1994. Direct measurement of sliding at the glacier bed. 7. Glaciol., 40(136), 595-599.

Blankenship, D. D., C. R. Bentley, S. T. Rooney and R. B. Alley. 1986. Seismic measurements reveal a saturated porous layer beneath an active Antarctic ice stream. Nature, 322 (6074), 54-57.

Boulton, G. S. and R. C. A. Hindmarsh. 1987. Sediment deformation beneath glaciers: rheology and geological consequences. f. Geophys. Res., 92(B9), 9059 9082.

Boulton, G. S. and A. S. Jones. 1979. Stability of temperate ice caps and ice sheets resting on beds of deformable sediment. F. Glaciol., 24 (90), 29-43.

Clarke, G. K. C. and E. W. Blake. 1991. Geometric and thermal evolution of a surge-type glacier in its quiescent state: Trapridge Glacier, Yukon Territory, Canada, 1969-89. 7. Glaciol., 37 (125), 158-169.

Clarke, G. K. C., S. G. Collins and D. E. Thompson. 1984. Flow, thermal structure, and subglacial conditions of a surge-type glacier. Can. J. Earth Sci., 21 (2), 232-240.

Dowdeswell, J. A., G. S. Hamilton and J. O. Hagen. 1991. The duration of the active phase on surge-type glaciers: contrasts between Svalbard and other regions. F. Glaciol., 37 (127), $388-400$.

Fischer, U. H. and G. K. C. Clarke. 1994. Ploughing of subglacial sediment. 7. Glaciol., 40 (134), 97-106.

Hambrey, M.J., J. A. Dowdeswell, T. Murray and P. R. Porter. 1996. Thrusting and debris entrainment in a surging glacier: Bakaninbreen, Svalbard. Ann. Glaciol., 22, 241- 248.

Hamilton, G. S. 1992. Investigations of surge-type glaciers in Svalbard. (Ph.D. thesis, University of Cambridge.) 
Humphrey, N., B. Kamb, M. Fahnestock and H. Engelhardt. 1993. Characteristics of the bed of the lower Columbia Glacier, Alaska. 7. Geophys. Res., 98(B1), 837-846.

Iverson, N. R., P. Jansson and R. LeB. Hooke. 1994. In-situ measurement of the strength of deforming subglacial till. f. Glaciol., 40(136), 497-503.

Iverson, N. R., B. Hanson, R. LeB. Hooke and P. Jansson. 1995. Flow mechanism of glaciers on soft beds. Science, 267 (5194), 80-81.

Kamb, B. and K. A. Echelmeyer. 1986. Stress-gradient coupling in glacier flow: I. Longitudinal averaging of the influence of ice thickness and surface slope. 7. Glaciol., 32(111), 267-284.

Murray, T. 1994. Glacial deformation. In Maltman, A., ed. The geological deformation of sediments. New York, Chapman and Hall, 73-93.
Murray, T. and P. R. Porter. 1994. Conditions at the bed of a high- Arctic surging glacier: Bakaninbreen, Svalbard. [Abstract.] EOS, $75(44)$, Supplement, 222.

Murray, T., D. L. Gooch and G.W. Stuart. 1997. Structures within the surge front at Bakaninbreen, Svalbard, using ground-penetrating radar. Ann. Glaciol., 24 (see paper in this volume).

Paterson, W. S. B. 1981. The physics of glaciers. Second edition. Oxford, etc., Pergamon Press.

Porter, P. R. and T. Murray. 1995. Bore-hole instruments to measure glacier basal motion. Leeds, University of Leeds. School of Geography. (Working Paper 95/21. 